\title{
Burying Straw at Greater Depths into soil Using Machinery
}

\author{
Pan Guangxin \\ College of Engineering, \\ Shenyang Agricultural University \\ Shenyang, China \\ E-mail: sdzcpop@163.com \\ Wang Ruili * \\ College of Engineering, \\ Shenyang Agricultural University \\ Shenyang, China \\ E-mail: rlwangsynd@163.com \\ * Corresponding Author
}

\author{
Yuan Yu \\ College of Engineering, \\ Shenyang Agricultural University \\ Shenyang, China \\ E-mail: yuanyu@163.com \\ Huang Yi \\ College of Land and Environment, \\ Shenyang Agricultural University \\ Shenyang, China \\ E-mail: emhuangyi@163.com
}

\begin{abstract}
The long term field scale experiment was performed for six years since 2008 in West-Liaoning Province, P. R. China. Furrows were made in autumn using deep-plough, straws were put into opened furrows using straw returning machine, and then the furrows were buried by soil back-filling plough and forming to ridges. The ridges were mulched by plastic film while seeding maize in spring. Deep furrowing action has led to broken plough pan, improved soil fertility through straw and fertilizer deep burial, reduced soil water evaporation because of plastic film mulching, and less soil disturbance by punch seeding. These interventions have helped in achieving greater yields because of improved soil-water-fertility condition. Mechanized planting reduces labor, increases efficiency, cuts down cost and improves profit. The mechanical operation through technology of burying straw at greater depths and planting maize by double line at one width ridge gap has achieved and the detailed procedure is presented in this paper. The necessary machinery selection and matching were also accomplished. Technology demonstration at BAJIA farm of Jianping County of China as an example was analyzed and the performance was tested by taking all inputs. The overall result showed increased net income of 7290 YUAN per hectare.
\end{abstract}

Keywords-Deep Tillage; Straw Returning; Mechanization Technology; Corn Stalks; Burying

\section{INTRODUCTION}

Drought, infertile soil, poor soil nutrient and other problems exist in North-East China. The rainwater resource is limited, since evaporation and runoff account for 74.6 percent of total rainfall. The tillage depth was analyzed and it shows an average of $16.08 \mathrm{~cm}$, which is $0.42 \mathrm{~cm}$ lower than that in other parts of China. According to soil nutrient content grading scheme, soil organic content, active $\mathrm{N}, \mathrm{P}$ and $\mathrm{K}$ in most dry land cropping are lower than grade 5 . The problem has become very serious which has direct influence on grain yield and hence food insecurity.

For the last 40 years, many projects were carried out to introduce new methods intended to optimize the efficiency of using limited water obtained by unbalanced rainfall (400 $\mathrm{mm}$ ) available in this region and to stop or reduce land degradation. As feasible options for improving the management of rainwater, water harvesting (WH) systems and techniques were suggested by many researchers [1-6]. Numerous WH techniques were investigated, such as the water-saving cultivation named "Ridge and furrow rainwater harvesting system", continuous and discontinuous contour furrow ridges of different shapes, sizes and spacing between furrows.

In recent years, ridge and furrow rainwater harvesting system has gradually become the main cultivation method in arid regions of China. In order to solve the problems of drought, shallow plough layer and low fertility in the arable soil of dry land regions in north of China, Shenyang Agricultural University has carried out testing of deep buried straw in the northwest area of Liaoning Province. The procedure continued with back filling of formed ridges and mulching with a plastic film in autumn and sowing seed in coming spring [7, 8]. After five years of experiment, maize yield was increased significantly. The yield of maize was high when water was enough, and was increased while water was normal, at the same time it was stable when the water was deficiency $[9,10]$. According to 
the results of demonstration and promotion, a technical theory of cross-seasonal adjustment for soil-fertilizer-water in dry land was put forward. Its main content includes open deep furrows using special designed plough, put straws into the opened furrows, and make soil ridges with machine in autumn after maize harvesting. Following this, in the coming spring, the maize was sowed in double lines on ridges while mulching plastic film. And the maize will be harvested without damaging the film in autumn. In the third year, seeds were sowed in the ridge; the seed fertilizer was also applied to the subsoil and at the same time.

\section{MATERIALS AND METHODS}

\section{A. Site description}

The field tests were carried out in the Bajia farm in Jianping County of Liaoning Province, where has continental monsoon climate, belonging to the dry farming area. The annual average temperature is $7-8^{\circ} \mathrm{C}$, annual rainfall is $300-500 \mathrm{~mm}$, and the distribution of rainfall is uneven and concentrated during June and August. The size of test field is $96 \mathrm{~m} \times 11.6 \mathrm{~m}$, the soil texture is sandy, and content of organize mater is $12 \mathrm{~g} \cdot \mathrm{kg}^{-1}$, Soil hardness is $1.4 \times 10^{6} \mathrm{~N} \cdot \mathrm{m}^{-2}$. The soil water content was $15 \%$ in soil layer of $0-10 \mathrm{~mm}$ depth.

\section{B. Experimental design}

After the corn harvest, furrows was made deeply furrow and ridge plough. Corn stalks were put into the furrows in October 2013. The amount of the corn stalks was $1.2 \times 10^{4} \mathrm{~kg} \cdot \mathrm{ha}^{-1}$. The fertilizer with diammonium phosphate $\left(600 \mathrm{~kg} \cdot \mathrm{ha}^{-1}\right)$, Potassium sulphate $\left(450 \mathrm{~kg} \cdot \mathrm{ha}^{-1}\right)$, Urea $\left(300 \mathrm{~kg} \cdot \mathrm{ha}^{-1}\right)$ and Fermentation agent $\left(35 \mathrm{~kg} \cdot \mathrm{ha}^{-1}\right)$ was supplied into the filed lay a precision planting machine on the mulched on May 10, 2014. The Zhengdan 958s corns were sowed. At the same time, operation quality was determined with measuring, straw returning, fertilizer application, ridging and film placing.

\section{RESULTS}

\section{A. Mechanized Technology analysis}

According to the agricultural requirements of dryland maize, after 5 years of practice, some equipment such as furrowing and ridging plough was developed, and the overall mechanized technology was established. The first step was mechanical deep furrowing. In order to break the plow pan and reduce soil bulk density, furrowing depth should be more than $35 \mathrm{~cm}$. The second step was deep burial of straw. Corn straw was backfilled in the furrow. The returning straw mass is about $1.2 \times 104 \mathrm{~kg} \cdot \mathrm{ha}^{-1}$ which was crushed, cut or no treatment. The third step was fertilizing. Fertilizer should be spread evenly, the fertilizer included diammonium phosphate $\left(600 \mathrm{~kg} \cdot \mathrm{ha}^{-1}\right)$, Potassium sulphate $\left(450 \mathrm{~kg} \cdot \mathrm{ha}^{-1}\right)$, Urea $\left(300 \mathrm{~kg} \cdot \mathrm{ha}^{-1}\right)$ and Fermentation agent $\left(35 \mathrm{~kg} \cdot \mathrm{ha}^{-1}\right)$. The carbon to nitrogen ratio met the requirement of crops. The fourth step was covering and ridging. Soil was backfilled in the furrow. In order to not affect the next sowing, the thickness of covering soil was more than $10 \mathrm{~cm}$. The fifth step was film mulching. Generally, in order to avoid damage the mulching in spring, a common thickness of the film was used. The film was 0.005 to $0.008 \mathrm{~mm}$ thick to save costs The sixth step was mulch sowing; corn was planted closely. Fig. 1 shows deep buried straw achieved through mechanization.

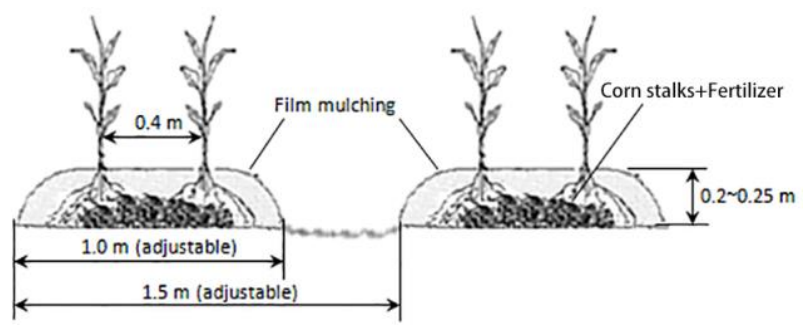

Figure 1. Showing corn planting method in arid

\section{B. Analysis and optimization of mechanization system}

Fig. 2 shows the mode of traditional technology for dry land maize. At each step, the technology would be finished with independent machine or human input. The dimension and volume of the furrow will be not enough to hold straws needed. If straw cannot be buried below plough layer, the soil cannot be improved $[11,12]$. According to traditional technology, many kinds of machines would be used. When tractors operate many times, it is very easy to affect the growth of crops. Moreover, the consumption of energy become very large, when total work time becomes longer [13].

Fig. 3 shows the mode of optimized operating. It improved the traditional mode, shortened operation time, improved work efficiency and reduced the operation cost. 


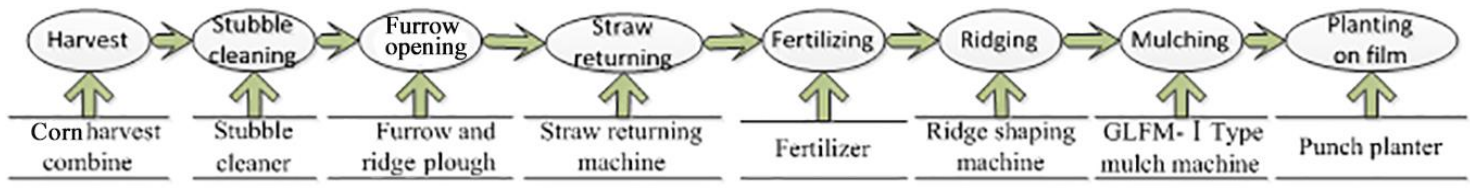

Figure 2. Mode of traditional machine operation

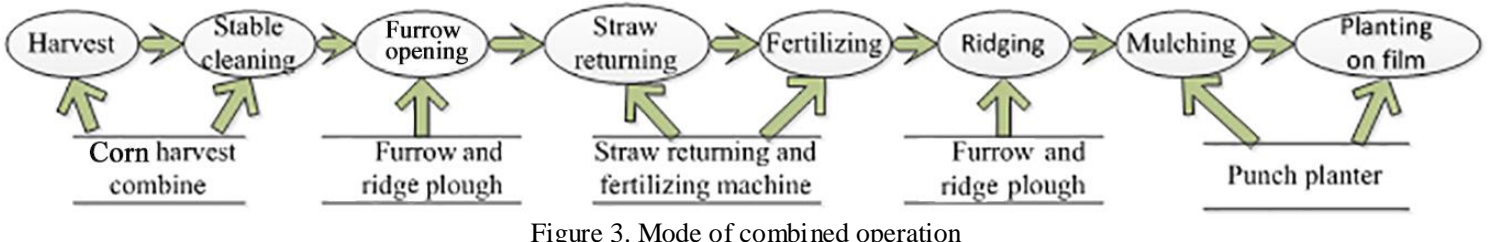

Figure 3. Mode of combined operation

\section{Analysis of mechanical technology \\ (1) Corn harvest}

The combine harvester will be used to harvest matured corn, meanwhile, soil stubble cleaning and corn stalks chopping need to be accomplished on the ground $[14,15]$. If the harvester cannot have stubble cleaning and chop corn stalks option, using stubble cleaner is necessary to have stubble cleaning. Or harvest corn and bundle the straw manually.

\section{(2) Mechanized furrowing and ridging}

In order to break the plow pan, place enough straw of $1.2 \times 10^{4} \mathrm{~kg} \cdot \mathrm{ha}^{-1}$ in the furrow and improve soil structure, the furrowing depth should be in the range of 30 to $40 \mathrm{~cm}$, width from 50 to $100 \mathrm{~cm}$ as per the premise of stable furrowing parameters. After backfilling of the straw in the furrow, the ridge was reshaped to be trapezoidal. The ridge height was $20 \mathrm{~cm}$, lower bottom width was 90 100 $\mathrm{cm}$, upper width was $70 \sim 80 \mathrm{~cm}$.

Furrowing and ridging plough was developed by the project team (Fig. 4). The plow frame is symmetrical; the each side is the isosceles triangle structure, and rotation adopts hydraulic turnover. Plough body is fixed at two surfaces of the frame. Two furrowing plough body, acted to turn over the soil, was put together. Two ridging plough body, installed separately, made the soil to form ridge.
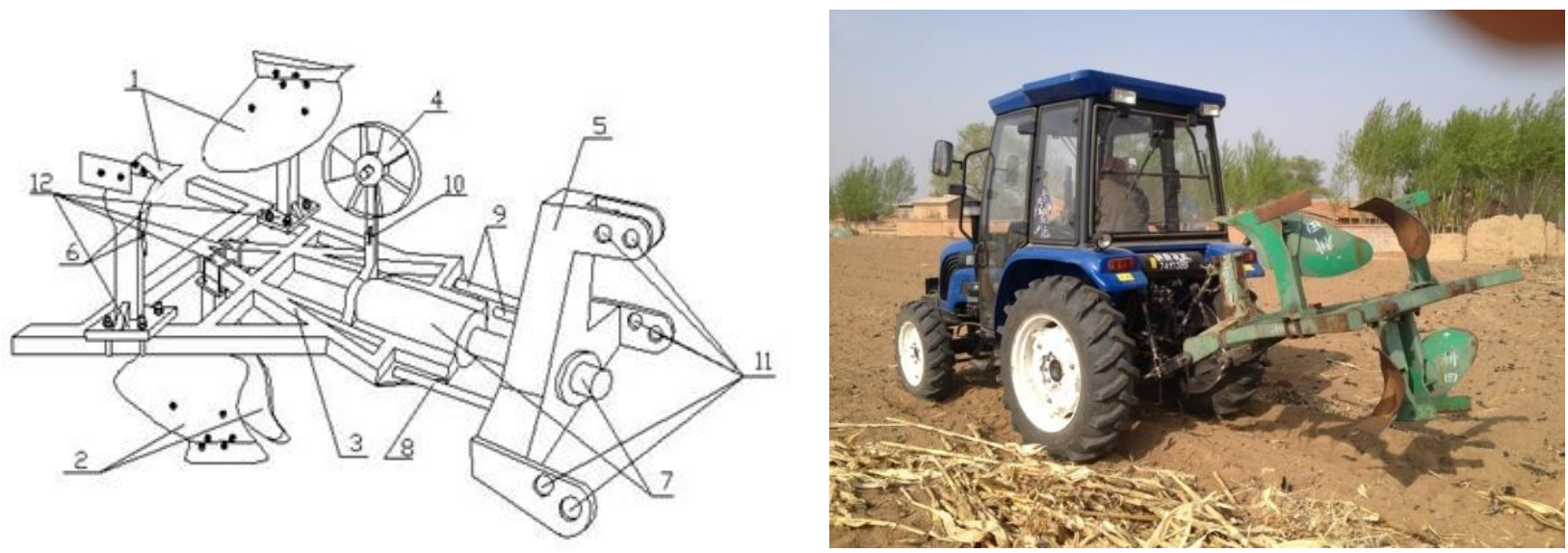

Figure 4. Schematic of furrowing and ridging plough

1. Ridging share 2. Furrowing share 3.Frame 4. Depth wheel

5. Headstock 6 Plough beam 7. Turnover mechanism 8.Sleeve piece 9.Fixed leg 10.Leg of depth wheel 11. Suspension connecting hole

This machine matched with tractor to achieve a draw power of $30 \mathrm{~kW}$. Furrowing depth was from 30 to $40 \mathrm{~cm}$, which is adjustable; furrow width was from 50 to $100 \mathrm{~cm}$, which is adjustable also; soil thickness is more than $10 \mathrm{~cm}$. Overall size is $2160 \mathrm{~mm} \times 1800 \mathrm{~mm} \times 1270 \mathrm{~mm}$. When furrowing, furrowing share was just under the plow frame, In order to ensure the requirements of the width of furrowing, the furrowing share position was adjustable .To prevent rotation, the plough frame was fixed. Furrowing depth controlled by hydraulic system. When ridging, plow turned 180 degrees, so that the plow frame can be in the horizontal position. At the same time, ridging share was below plough frame. In order to ensure the requirements of the width of ridging, the ridging share position was adjustable. Ridge height was controlled by depth wheel. 
While ridging and furrowing, the depth wheel pressed the backfilled returning straw.

\section{(3) Straw returning and fertilizing}

After furrowing, straw was returned and fertilizer would be applied. The amount of returning straw is $1.2 \times 104 \mathrm{~kg} \cdot \mathrm{ha}^{-1}$, and fertilizer includes diammonium phosphate $\left(600 \mathrm{~kg} \cdot \mathrm{ha}^{-1}\right)$, Potassium sulphate $\left(450 \mathrm{~kg} \cdot \mathrm{ha}^{-1}\right)$, Urea $\left(300 \mathrm{~kg} \cdot \mathrm{ha}^{-1}\right)$ and Fermentation agent $\left(35 \mathrm{~kg} \cdot \mathrm{ha}^{-1}\right)$, so that it can adjust the soil $\mathrm{C} / \mathrm{N}$. While fixing the fertilizing device in straw return machine, straw was not only backfilled in the furrow but also fertilizer application was done (Fig.5).

\section{(4) Mulching and planting}

Combination of mechanical seeding with other operations was accomplished. Using 2BMF-2 precision mulch planting machine to sow seed, and film laying with white or black film at a width of $1.5 \mathrm{~m}$ was down(Fig.6). Sowing depth, uniformity and space met the agronomic requirements. Plant spacing is $40 \mathrm{~cm}$, and row spacing is $20 \mathrm{~cm}$.

\section{Quality of furrowing and ridging}

According to Filed operation quality of ditchers (NY/T 740-2003), two furrow distance was selected in the test area. Taking 5 samples each $50 \mathrm{~m}$ and in total it was 10 samples. Before the measurement, the furrow was cleaned, and a ruler was placed at the surface between two walls. The distance from the center point of furrow bottom to the ruler distance is furrow depth (h). Similarly, the width of furrow bottom and furrow surface can be measured. According to formula from (1) to (4), the average value, standard deviation of furrowing parameters,

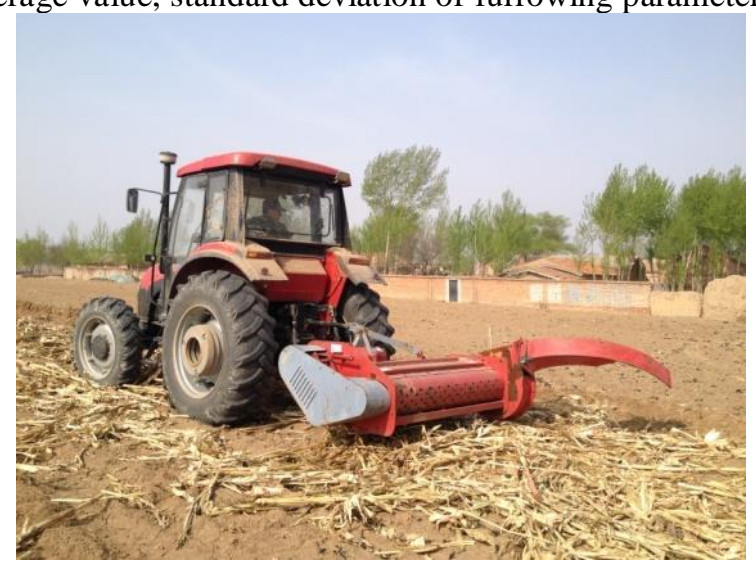

(a) Corn stalk chipper coefficient of variation and stability coefficient can be calculated.

Average $\bar{h}$ :

$$
\bar{h}=\frac{\sum_{i=1}^{N} h_{i}}{N}
$$

Standard deviation $S$ :

$$
S=\sqrt{\frac{\sum_{i=1}^{N}\left(h_{i}-\bar{h}\right)^{2}}{N-1}}
$$

Coefficient of variation $v$ :

$$
v=\frac{S}{h} \times 100 \%
$$

Coefficient of stability $U$ :

Where, $h$-average of furrowing depth, $\mathrm{cm} ; h_{l}$ Furrowing depth value of the measurement points, $i=1 \sim 10, \mathrm{~cm} ; \mathrm{N}$ - the number of observation points in the test area, $N=10$;

After analyzing the results, the furrow shape was trapezoidal. As shown in Table 1, the furrowing parameters meet the agricultural requirements of deep buried straw. Similarly, with the same method, the ridging parameters were obtained. As shown in Table 1, the ridging parameters also meet the agricultural requirements of deep buried straw.

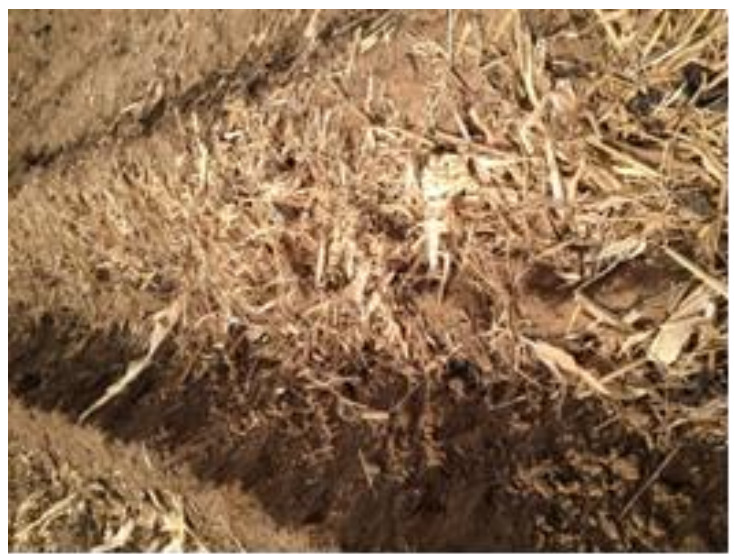

(b) Filled chopped corn stalks 

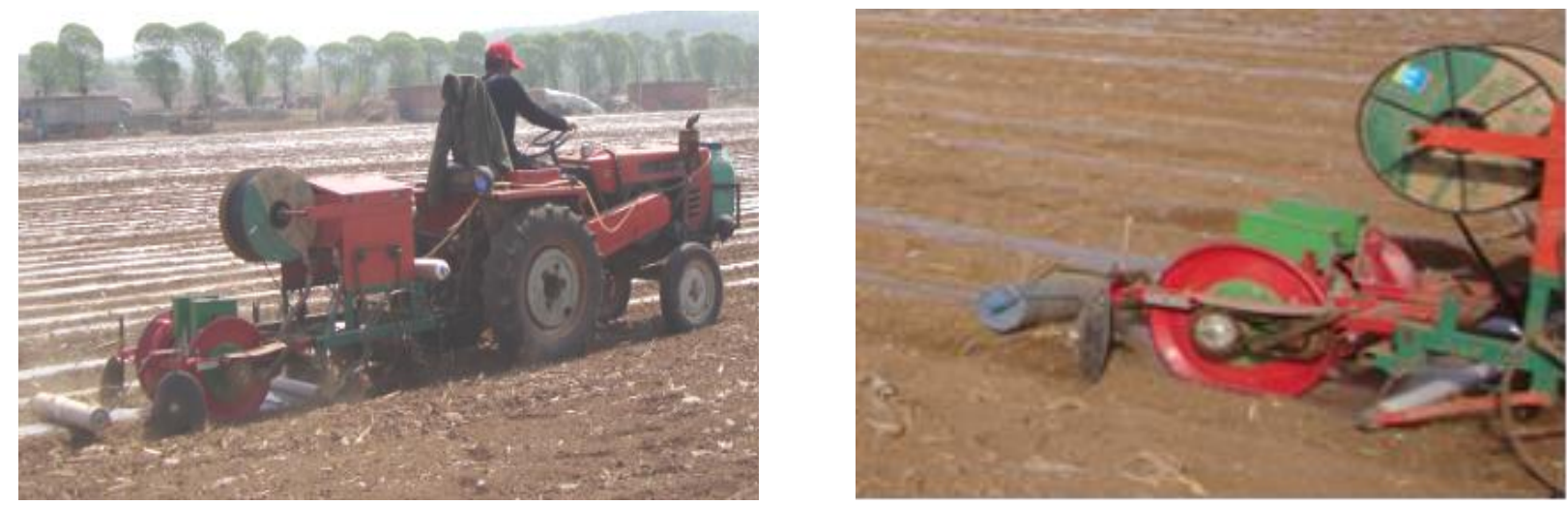

Figure 6. Mulch planter

TABLE 1. FEATURES OF FURROWS AND RIDGES

\begin{tabular}{|c|c|c|c|c|}
\hline Test item & $\begin{array}{c}\text { Average } \\
\text { mm }\end{array}$ & $\begin{array}{c}\text { Standard deviation } \\
\mathrm{mm}\end{array}$ & $\begin{array}{c}\text { Coefficient of variation } \\
\%\end{array}$ & $\begin{array}{c}\text { Coefficient of stability } \\
\%\end{array}$ \\
\hline Furrow depth & 298.5 & 13.9 & 4.66 & 95.34 \\
\hline Width of furrow surface & 831 & 19.7 & 2.37 & 97.63 \\
\hline Width of furrow bottom & 397 & 9.5 & 2.39 & 97.61 \\
\hline Ridge height & 217.8 & 13.6 & 6.25 & 93.75 \\
\hline Width of ridge surface & 366.6 & 12.3 & 3.37 & 96.63 \\
\hline Width of ridge bottom & 1028.4 & 9.5 & 0.93 & 99.07 \\
\hline Thickness of soil covering & 103 & 5.8 & 5.63 & 94.37 \\
\hline
\end{tabular}

\section{E. Quality of returning straw and fertilization}

According to Technical specifications of quality evaluation for smashed straw machine (NY/T 1004-2006) and Equipment for distributing fertilizers-Test methodsPart 2: Fertilizer distributor in line (GB/T 20346.2-2006), the operation quality of straw returning and fertilization was tested. The results showed that fertilization amount and uniformity met the agronomic requirements.

\section{F. Quality of mulch planter}

According to Seed sowing machine for the mulching film (B/T 7732.2-1995) and Operating Quality of Single (precision) Seeder for Inter-tilled Crops (NY/T 503-2002), the operation quality was measured, including seeding rate, seeding distance, sowing depth and row spacing. The results showed that the mulching and planting operation met the agronomic requirements.

\section{CONCLUSIONS}

The results show that mechanization technology is suitable for the agricultural technical requirements of returning straw, soil fertility and water resources regulation in northwest region of Liaoning. Moreover, the operation quality of Furrowing and ridging plough met the agricultural requirements.

\section{ACKNOWLEDGMENT}

This work was financed by Ministry of Agriculture of China (201503134, 200903007 and 201303125). Researchers would like to thank Mr. Zhao Kai and Mr. Zhao Fengxi for managing the field experiment.

\section{REFERENCES}

[1] Wu Wei and Liao Yuncheng, "The research progress and prospects of ridge and furrow rainwater harvesting system in arid regions of China," Acta Agriculturae Boreali-Occidentalis Sinica, vol 2, 2014, pp. 1-9

[2] Li Shangzhong, Fan Tinglu, Wang Yong, Zhao Gang, Wang Lei, Tang Xiao-ming, Dang Yi and Zhao Hui, "Effects of plastic film mulching and rain harvesting modes on chlorophyll fluorescence characteristics, yield and water use efficiency of dryland maize," Chinese Journal of Applied Ecology, vol 2, 2014, pp. 458-466.

[3] Wang Qingjie, Li Hongwen, He Jin, Li Wenying and Liu Andong, "Effects of wide-ridge and narrow-row no-till cultivation on soil water and maize yield," Transactions of the CSAE, vol 8, 2010pp. 39-43.

[4] Zhang Jianxin and Zheng Dawei, "Advances and expectations of international rainwater catchment researches," Agricultural Research in the Arid Areas, vol 2, 2005, pp.223-229.

[5] Christian Bugge Henriksen, Jesper Rasmussen and Carsten Søgaard, "Ridging in autumn as an alternative to mouldboard ploughing in a humid-temperate region," Soil \& Tillage Research, vol 85, 2005, pp.27-37.

[6] Christian Bugge Henriksen, Jens Peter Mølgaard and Jesper Rasmussen, "The effect of autumn ridging and inter-row subsoiling on potato tuber yield and quality on a sandy soil in Denmark," Soil \& Tillage Research, vol 93, 2007, pp.309-315.

[7] Li Zhen, Zhao Yanyan and Wei Tiexia, Huang Y, "Analysis on the main problems in dry land farming soil in western Liaoning," Journal of Shanxi Agricultural Sciences, vol 11, 2013, pp.12051208,1211 .

[8] Huang Yi, Li Zhen and Yu Xian, "Operation technique of combined cross-seasonal adjustment on soil, fertilizer and water in dry land maize," New Agriculture Magazine, vol 07,2011, pp.37-38.

[9] Wang Ruili, Huang Yi, Wei Fenglan, Bai Xuewei, Liu E and Zhang Yulong, "Design and testing of plough for deep furrowing and ridging of straw amendment fields," Journal of Shenyang Agricultural University, vol 2, 2012, pp.231-234. 
[10] Huang Yi, Wang Ruili and Zhao Kai, "Effects of deep moisture and fertility regulation on main physical properties of soil and yield of maize in dry land regions in western Liaoning Province," Agricultural Research in the Arid Areas, vol 1, 2013, pp.8-13.

[11] Den Yueying, "Corn harvest mechanization technology and problems," Heilongiiang Science and Technology Information, vol 16, 2012, pp.206.

[12] Zhang Jigao, Li Mingzhe, Ma Zhihong, Zheng Xiakun, Wang Yuxian and Ma Baoshan., "The study of the mechanized farming processes of corn, kaoliang, soy bean and millet of Shenyang district," Journal of Shenyang Agricultural University, vol 4, 1963, pp.131-140.

[13] Xue Jian, Li Fengchao, Li Zengjia, Han Xingguo, Yu Hongxin and Zhang Ning, "Studies on the effect of harrowing straw into fileds( II )The mechanical operation technology and necessary machinery in harrowing straw into field," Journal of Shandong Agricultural University,vol 04, 1986, pp.37-43.

[14] Jia Honglei, Wang Lichun. Li Chunsheng, Tan Hongjie and Ma Chenglin, "Combined stalk-stubble breaking and mulching machine Original," Soil and Tillage Research, vol 1, 2010, pp.42-48.
[15] Jia Honglei, Ma Chenglin, Li Guangyu, Huang Dongyan, Liu Zhaochen, "Combined rototilling-stubble-breaking-planting machine Original," Soil and Tillage Research, vol 2, 2007, pp.73-82.

[16] Machinery industry standard of the People's Republic of China. JB/T 7732-2006 Mulching planter, 2007.

[17] Agricultural industry standard of the People's Republic of China. NY/T 1004-2006 Technical specifications of quality evaluation for smashed straw machine, 2006.

[18] PRC National Standard. GB/T 20346.2-2006 Fertilizing machine. Experiment method. Part 2: Fertilizer used between plant spaces, 2006.

[19] Agricultural industry standard of the People's Republic of China. NY/T 503-2002Operating quality of single (precision) seeder for intertilled crops, 2002.

[20] Agricultural industry standard of the People's Republic of China. NY/T 740-2003 Field operation quality of ditchers, 2004 